e ISSN-0976-7223 | Visit Us - www.researchjournal.co.in

DOI : 10.15740/HAS/IJAE/7.2/395-398

\title{
Mathematical modeling of physical properties of banana (Musa acuminata) stored under different temperature conditions
}

\section{A. KARTHIAYANI, M. SIDDHARTH AND N. VARADHARAJU}

Received : 29.04.2014; Revised : 21.08.2014; Accepted : 05.09.2014

See end of the Paper for authors' affiliation

Correspondence to :

\section{A. KARTHIAYANI}

College of Food and Dairy

Technology, Tamil Nadu

Veterinary and Animal

Sciences University, CHENNAI

(T.N.) INDIA

Email : mankarthi@yahoo.com
- ABSTRACT : Respiration is a process of oxidative breakdown of organic matter present in the cells into simpler molecules along with concurrent production of energy and other molecules which can be used by the cell for synthetic reactions. Respiration rates have been used as an index for the metabolic activities of fruits during ripening and senescence. The respiration process depends on the physical properties like mass, volume and surface area of the produce. In the present study, the physical properties were determined and modeled using the graphical method. The respiration rate was determined at three different temperatures (ambient, $14^{\circ} \mathrm{C}$ and $24^{\circ} \mathrm{C}$ ) by using formula method and the same was modeled based on enzyme kinetic reactions as per Michaelis- Menten type of equation using non-linear regression in Sigmaplot 8.0 software. Results indicated that the mathematical model was found to be good fit.

- KEY WORDS : Banana, Physical properties, Respiration rate, Model, Sigmaplot 8.0

— HOW TO CITE THIS PAPER : Karthiayani, A., Siddharth, M. and Varadharaju, N. (2014). Mathematical modeling of physical properties of banana (Musa acuminata) stored under different temperature conditions. Internat. J. Agric. Engg., 7(2) : 395-398. 